\title{
SPIDERS REVISITED: RETRACING THE STEPS OF HERBERT AND LORNA LEVI'S HISTORIC INVERTEBRATE SURVEYS OF THE JACKSON HOLE REGION OF WYOMING
}

\author{
SARAH J. KARIKO ${ }^{1,2} \nrightarrow$ DANIEL ROSSMAN $^{2}$ \\ ${ }^{1}$ MUSEUM OF COMPARATIVE ZOOLOGY $\uparrow$ CAMBRIDGE, MA \\ ${ }^{2}$ CRAighead Beringia SOUTH $\uparrow$ Kelly, WY \\ ${ }^{2}$ GOSSAMER LABS, LLC $\downarrow$ BURLINGTON, VT
}

\begin{abstract}
$\downarrow$ ABSTRACT
In 1950, Herbert and Lorna Levi collected invertebrates in Yellowstone and Grand Teton National Parks and other localities in the region. Sixty-five years later and looking towards the centennial of the National Park Service, a preliminary reassessment of the biodiversity of spiders was conducted in a subset of localities that were collected by the Levis. Specimens have been collected and are in the process of being identified. Comparison of this new collection with the historical records is currently underway. As the arts have played a crucial role in the history of national parks, we are exploring how to partner art and science to share the beauty and wonder of spiders based on our fieldwork in celebration of the upcoming National Park Service centennial.
\end{abstract}

\section{$\downarrow \quad$ INTRODUCTION}

The purpose of this study is to conduct a preliminary reassessment of the biodiversity of spiders in select locations in Grand Teton National Park and the surrounding area and to compare our assessment to historical records. It is part of a larger project to explore using spiders as a way of thinking about interconnectedness, innovation and stewardship.

\section{Herbert Walter and Lorna Rose Levi}

Herbert Walter Levi (3 January 1921 - 3 November 2014) was one of the "grand arachnologists of the $20^{\text {th }}$ century" (Maddison 2014) and is known for his contributions to spider taxonomy, especially orb-weaving spiders. While in Wisconsin, Levi said he attended every lecture he could by Aldo Leopold, considered by some to be the father of wildlife ecology and the United States wilderness system, in order to learn everything he could and apply it to invertebrates (Levi, pers. com.). Levi later became the Alexander Agassiz Professor of Zoology and the Curator of Invertebrate Zoology at Harvard's Museum of Comparative Zoology. As an alpha taxonomist Levi described more than 1,250 species of spiders new to science during his career. He left a long lineage of students including curators of invertebrates at institutions like the American Museum of Natural History and the Smithsonian, and he made spiders accessible to people through his drawings and work at a time when macro field photography and the imaging techniques we have now were not so readily available. Along with his wife Lorna (who was a coinvestigator on much of his research), the Levis dedicated their lives to arachnology, conservation, education and stewardship, and they shared their fascination with spiders with broad audiences through their classic book: "Spiders and Their Kin" (Frances Levi, personal communication; Levi et al. 1968).

In 1950, the Levis travelled from Wisconsin to Wyoming to conduct some of the first surveys of terrestrial invertebrates in the area. The Levis were stationed at the Jackson Hole Wildlife Park from July 15 to August 15, 1950 (Figure 1). The purpose of their study was to "obtain specimens of several groups of invertebrates of the Jackson Hole region for purposes of study of their taxonomy, ecology, life history and distribution" (Levi and Levi 1951a). The Levis travelled to various field sites to collect and attended lectures by other researchers including a talk that summer by Olaus Murie (Levi and Levi, pers. com.). 


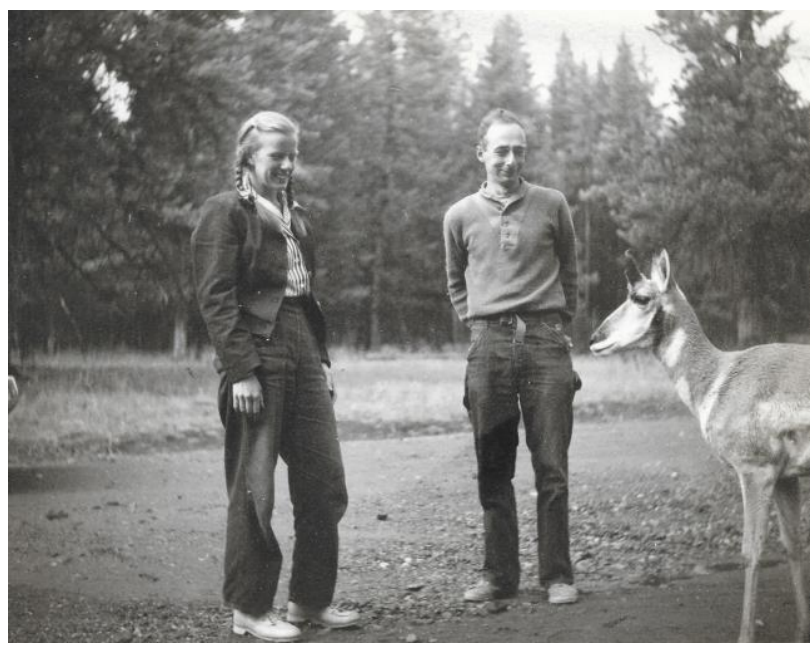

Figure 1. Lorna and Herbert Levi and a pronghorn antelope in the GYE, 1950 (photo courtesy Frances Levi).

\section{Spiders and invertebrate conservation}

Invertebrates make up more than 95 percent of animal species - they are some of the "little things that run the world" according to E. O. Wilson (Wilson 1987). Despite their being the most abundant creatures on our planet (Smithsonian Institution 2014), there are fewer and fewer places where people can learn about invertebrates. Last year the National Zoo permanently closed its Invertebrates Exhibit. As NPR's Christopher Joyce reported over ten years ago, these animals have been a tough sell for conservation efforts because they "are not furry" and "they don't eat out of your hand...but their disappearance would fundamentally change our planet" (Joyce 2004).

Of the invertebrates, there are 45,756 accepted species of spiders according to the World Spider Catalog (2015), compared to the eight species of bears living in the world (Servheen et al. 2009) - only two of which make their home in the Greater Yellowstone Ecosystem (GYE) (Gunther et al. 2002). Spiders have been found in every terrestrial ecosystem (except in Antarctica) as well as in some aquatic ones. Spiders play an important role in the food web as both predator and prey. As predator, they help control the insect and pest populations that could otherwise devour the plants that are food sources for many animals such as the herds of bison important to the American West, and as prey they are a food source for birds, wasps, frogs and other animals. All spiders can spin silk, although not all spiders make webs. Most spiders produce venom that they use to assist with prey capture. Spiders capture their prey using a variety of strategies usually involving some combination of venom and silk. Spiders are considered the most abundant predator on land today (Selden and Penny 2010).

\section{Spiders and innovation}

Spiders' incredible diversity is rich territory for bio-inspired design. Spiders (specifically their venom and silk) are a focal point for many areas of research: from medical and pharmaceutical applications (Blüm and Scheibel 2012); to biotechnology (Blum et al. 2014, Chaim et al. 2011, Senff-Ribeiro et al. 2008); to agricultural pesticide research (Nakasu et al. 2014). Former University of Wyoming Professor Randy Lewis, currently the Director of the Synthetic Bioproduct Center at Utah State University, has made significant contributions with his research of spider silk proteins toward synthetic spider silk production (Utah Statesman 2011, Dong et al. 1991). Jackie Palmer, one of Levi's students, also played an important role in advancing knowledge of spider silk through her research on silk production in "primitive" mygalomorph spiders (Palmer 1985, 1990, Shear et al. 1989). Through their scientific contributions, along with the research of many others who have looked to spiders for inspiration over several centuries, they advanced knowledge on how to synthesize a fiber whose ratio of strength to density exceeds that of steel and is more flexible than Kevlar (Oyen 2013) something spiders have been doing for over 400 million years on a liquefied diet of dead bugs (Brunetta and Craig 2010). This has led to recent innovations such as the North Face's Moon Parka that is "the world's first successful use of synthetic spider silk materials on an actual manufacturing line" (North Face 2015).

\section{Spiders and the Greater Yellowstone Ecosystem}

Despite their ecological importance and remarkable diversity, research on spiders in Grand Teton National Park has advanced little since the 1950s when Levi and Levi conducted their surveys in the then Jackson Hole Wildlife Park and surrounding areas (Donald Lowrie and Willis Gertsch studied spiders from the western Wyoming region during the early 1950s as well) (Levi and Levi 1951b, Lowrie and Gertsch 1955, Lowrie 1968). As of December 2015, the IRMA National Park Service database lists fortythree "Spider/Scorpion" records in Yellowstone, and only one, a mite, in Grand Teton National Park (National Park Service 2015a). This number is not commensurate with their abundance nor their importance.

\section{Art and conservation}

Art has played an important role in protecting the natural environment. Paintings by Thomas Moran and photographs by William Henry Jackson captured the imagination of the young nation and are credited with helping to convince Congress to establish Yellowstone as the first National Park in 1872 (Cantrell 2014). The depiction of some animals through artwork has raised awareness, shifted public attitudes and inspired actions. 
Audubon's accomplishments as a bird artist sparked awareness and inspired the formation of the Audubon Society in the $1800 \mathrm{~s}$, an organization that remains committed to science-based bird conservation and continues to use his images in their conservation efforts (Audubon Society 2015). Photographs were crucial for building public support and moving lawmakers to designate lands for conservation - the photographs by N. S. Leek of the wasting elk were instrumental in moving the public and Congress to found the National Elk Refuge in 1912 (Morriss 2012).

Exploring and nurturing our connection with nature through art continues today in various forms: from the Ucross Pollination Experiment that paired prominent artists and scientists from the University of Wyoming to create original works (University of Wyoming 2014); to Jackson Hole Public Arts commissions for celebrating endangered species in the GYE (Daly 2013); to the multidisciplinary performance Hi-Fi Sci Art: Preserving Our Planet with Dinosaur Annex at the MIT Museum (Massachusetts Institute of Technology 2015); to the exhibits and dialogue sparked by the National Museum of Wildlife Art and its public programming that "enrich and inspire appreciation and knowledge of humanity's relationship with nature" (National Museum of Wildlife Art 2015); to Arts for the Parks, where artists create works inspired by the parks and a portion of the proceeds goes back to supporting the parks (Grand Teton Association 2015).

While successful in communicating the grandeur of the region, some of the early iconic images of the American West (such as Moran's paintings from the Hayden Geological Survey of 1871) did not represent the reality of native peoples inhabiting the land. Moran's daughter said of her father's experience, "To him it was all grandeur, beauty, color and light - nothing of man at all, but nature, virgin, unspoiled and lovely" (Wilkins 1998). Native peoples are still marginalized and frequently underrepresented in the story of our national parks. Many of the lands in the northern Rocky Mountain west referred to as "untouched wilderness" were actually lands important to tribes such as the Blackfoot, Shoshone, Bannock, Gros Ventre and others. Evidence of indigenous peoples in the area of Grand Teton National Park dates back at least 11,000 years (National Park Service 2015b, Crockett 1999).

\section{Spiders and stories}

From early cave drawings that depicted spiders, to the oral tradition of Anansi spider stories of the Ashanti/Asante people of West Africa, to the Greek's stories of Arachne, to Hollywood's live action spiderman stories, spiders have touched human imagination and inspired stories among peoples around the globe and across time (Hillyard 1994, Michalski 2010). Spiders are important in many Native American cultures, ranging from Na'ashjéii Asdzáá, Spider Woman, who lives atop Spider Rock in Canyon de Chelly and taught the Diné weaving (Locke 2001), to traditional instructional stories of Iktomi, the trickster spider of the Sioux (Zitkala-Sa 1985). Contemporary native artists pull from traditional imagery to create striking, thought-provoking works important for our times.

\section{$\uparrow \quad$ STUdY AREA}

We revisited a subset of the Levi's field localities in Grand Teton National Park from the Levi and Levi (1951a) study and collected invertebrate specimens focusing on the arachnofauna.

\section{$\uparrow$ METHODS}

We retraced part of Herbert and Lorna Levi's invertebrate field collections in the Jackson Hole region in 1950. Permission was obtained from the Levi family to use original materials from this fieldwork and from the Craighead family to use their original vegetative survey maps from 1950 to guide our work. Our team was joined by the Levi's daughter, Frances, who assisted us in sampling a subset of the original field sites that were studied by her parents. Derek Craighead assisted with spider collection as well. Animals were observed in the field, photodocumented in situ when possible or in the lab, then collected.

Project methods have been approved by the respective permitting authorities and modified accordingly. This research is conducted under research permit\# GRTE2015-SCI-0065 obtained from the Grand Teton National Park in the summer of 2015.

Collection techniques included sweep netting, hand collecting, litter sifting, and beating. Field teams conducted sampling both diurnally and nocturnally (usually two collectors during diurnal collecting; usually teams of three collectors for nocturnal collecting). Pitfall traps were not used during this past field season and will only be used in future work on a case-by-case basis per agreement with the National Park Service. Spiders were preserved in $20 \mathrm{~mL}$ scintillation vials containing $95 \%$ ethanol solution.

\section{$\downarrow \quad$ PRELIMINARY RESUltS}

Over the course of our fieldwork in July and August, we observed, collected, and photo-documented (Figure 2) representative species of spiders (Arachnida: Araneae) from selected sites that were originally surveyed by Levi and Levi (Figure 3). The historic Levi collection can be accessed at MCZ base: http://www.mczbase.mcz.harvard.edu and may be used as a 
comparative basis and future research. We are working with the National Park Service (NPS) curator to create a database and collection for our study in compliance with NPS curatorial protocols.

A preliminary contribution at the junction of the arts and science is the poem "Populus tremuloides: We Are One" written by S. J. Kariko that highlights our interconnectedness and is inspired by events from this summer's field season. It was selected to be read at Wonder Of The World, a benefit for the environment on the eve of the international climate talks in Paris in November 2015.

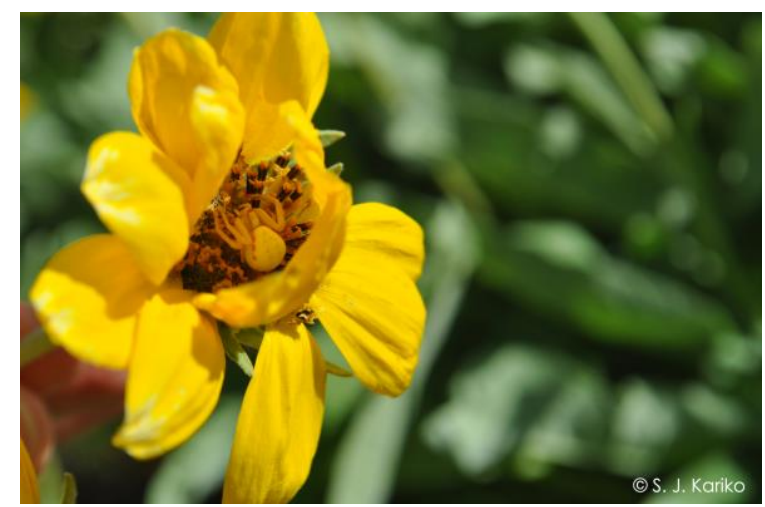

Figure 2. Female crab spider Misumena vatia, (Thomisidae) collected in 2015 (Photo credit S. J. Kariko)

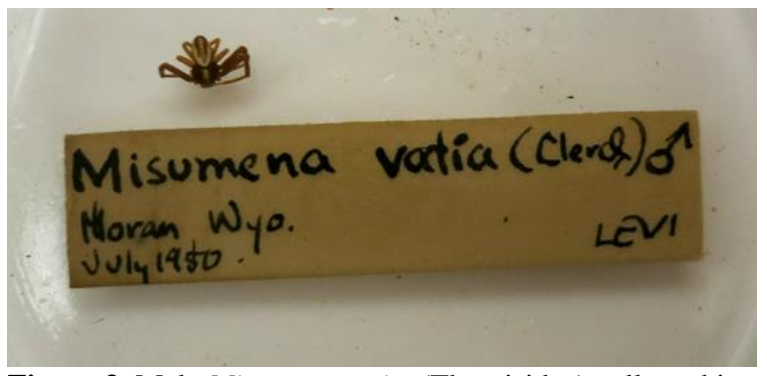

Figure 3. Male Misumens vatia, (Thomisidae) collected in 1950 in Moran, WY by Herbert and Lorna Levi. (C) President and Fellows of Harvard, Museum of Comparative Zoology

\section{$\downarrow \quad$ DISCUSSION AND FUTURE WORK}

Spiders also give us the metaphor of the web - a way to think about our own interconnectedness and interdependence in both the natural and global world. Engaging visitors through art and science can spark imaginations, inspire discussion, and foster conditions for creative collaborations that can help us develop innovative solutions to meet today's challenges. To this end, our team is exploring how to create an invitation for visitors to learn about some of the little creatures in Grand Teton National Park during next summer's centennial celebration through sharing the beauty and wonder of spiders. We envision that art, including contemporary Native works, with its ability to communicate as the "universal language" will be an important vehicle to reach a diverse audience. In celebration of the centennial and to the Levi's legacy, we aim to create work that combines not only the legacy of Herb's arachnological research but also the conservation, storytelling and stewardship that were so important to both of them.

\section{$\downarrow$ ACKNOWLEDGEMENTS}

We would like to thank Dr. Harold Bergman and the UW-NPS Research Center crew for their hospitality and logistical support and Celeste Havener for assistance with station housing; Frances Levi for providing instrumental fieldwork and sharing family photographs and stories; Derek Craighead for his assistance in the field, and for providing, together with Charlie Craighead, their fathers' historic vegetation map of the Jackson Hole Wildlife Park (JHWP); Dr. Hank Harlow for sketching the map that helped us locate the JHWP site; Sue Consolo-Murphy, Bridgette Guild, Liz Barrett, Sarah Dewey and the GRTE team for facilitating collecting permits and research. Thanks to Jane Lavino, Marilyn Cuthill, Agnes Bourne, Stu Plummer, Jim Luebbers and Red Ants Pants for project support; Professor Gonzalo Giribet for hosting SJK's research in the Invertebrate Zoology Collections at Harvard's Museum of Comparative Zoology and curatorial staff Adam Baldinger, Laura Leibensperger and Kate Sheridan for collections assistance. Funding was provided by Craighead Beringia South and Gossamer Labs, LLC. This research was partially supported by a housing subsidy from the University of Wyoming-National Park Service Research Station (http://uwnps.org).

\section{$\downarrow$ Literature CiTED}

Audubon Society. 2015. John James Audubon. Washington, DC. www.audubon.org/content/johnjames-audubon. Accessed 29 Dec. 2015.

Blüm, C., and T. Scheibel. 2012. Control of drug loading and release properties of spider silk submicroparticles. BioNanoScience 2.2:67-74.

Brunetta, L., and C. L. Craig. 2010. Spider Silk. Yale University Press.

Cantrell, M. 2014. Thomas "Yellowstone" Moran: Influencing Change with Art. National Parks Conservation Association. www.npca.org/articles/376-thomas-yellowstonemoran-influencing-change-withart\#sm.00005m4j3g100tfd8q4zyelcv9te5. Accessed 29 Dec 2015.

Chaim, O. M., et al. 2011. Brown spider (Loxosceles genus) venom toxins: Tools for biological purposes. Toxins 3.3:309-344. 
Crockett, S. 1999. The prehistoric peoples of Jackson Hole. In: A Place Called Jackson Hole: The Historic Resource Study of Grand Teton National Park. J. Daugherty (ed.), Grand Teton Natural History Association, Moran, WY. www.nps.gov/parkhistory/online_books/grte2/hrs 2.htm. Accessed 31 Dec 2015.

Daly, M. 2013. Arts: public art. Homestead Magazine. Circ Design, n.d. homesteadmag.com/article/jacksonhole-public-art/. Accessed 6 Dec. 2015.

Dong, Z., R.V. Lewis, and C. R. Middaugh. 1991. Molecular mechanism of spider silk elasticity. Archives of biochemistry and biophysics 284.1: 53-57.

Gunther, K.A., et al. 2002. Probable grizzly bear predation on an American black bear in Yellowstone National Park. Ursus 13: 372-374.

Grand Teton Association. 2015. Plein Air for the Park. Grand Teton Association, Moran, WY. https://www.grandtetonpark.org/our-work-forthe-park/plein-air-for-the-park/. Accessed 6 Dec. 2015.

Hillyard, P.D. 1994. The Book of the Spider: From Arachnophobia to the Love of Spiders. Random House Inc.

Joyce, C. 2004. Saving the world's spineless. NPR. National Public Radio, 31 Mar. 2004. www.npr.org/templates/story/story.php?storyId=1 803582. Accessed 13 Dec. 2015.

Levi, H.W., and L.R. Levi. 1951a. Preliminary Report on Research Concerning Terrestrial Invertebrates made at the Jackson Hole Wildlife Park July 15, to August 15, 1950.

Levi, H.W., and L. Levi. 1951b. Report on a collection of spiders and harvestmen from Wyoming and neighboring states. Zoologica 36: 219-237.

Levi, H.W., L.R. Levi, and H.S. Zim. 1968. Spiders and their Kin. Macmillan.

Locke, R.F. 2001. The Book of the Navajo. Holloway House Publishing.

Lowrie, D.C. 1968. The spiders of the herbaceous stratum of the Jackson Hole region of Wyoming. Northwest Sci 42.3: 89-100.

Lowrie, D.C., and W.J. Gertsch. 1955. A list of the spiders of the Grand Teton Park area: With descriptions of some new North American spiders. American Museum novitates. no. 1736.

Maddison, W. 2014. Och, my head is full of spider genitalia! Wayne Maddison Lab. 5 Nov. 2014. waynemaddisonlab.wordpress.com/2014/11/05/oc h-my-head-is-full-of-spider-genitalia/. Accessed 30 Dec. 2015.

Massachusetts Institute of Technology. 2015. Cambridge Science Festival. MIT Museum. www.cambridgesciencefestival.org/. Accessed 31 Dec. 2015.
Michalski, K., and Sergiusz. 2010. Spider. Reaktion Books. Morriss, S. 2012. National Elk Refuge: 1912 - 2012. Jackson Hole Historical Society and Museum. jacksonholehistory.org/national-elk-refuge-19122012/. 20 Apr. 2015.

Nakasu, E., et al. 2014. Novel biopesticide based on a spider venom peptide shows no adverse effects on honeybees. Proceedings of the Royal Society of London B: Biological Sciences 281.1787: 20140619.

National Museum of Wildlife Art. 2015. Mission and Vision. www.wildlifeart.org/about/about-themuseum/mission-and-vision/. Accessed 30 Dec. 2015.

National Park Service. 2015a. NPSpecies. U.S. National Park Service. irma.nps.gov/NPSpecies/. Accessed 31 Dec. 2015.

National Park Service. 2015b. American Indians. U.S. National Park Service. www.nps.gov/grte/learn/historyculture/ind.htm. Accessed 31 Dec. 2015.

North Face. 2015. Announcing MOON PARKA: A jointly developed prototype heading for commercialization from The North Face in 2016. Press Release. Nov. 2015, www.goldwin.co.jp/en/corporate/info/page-9331. Accessed 31 Dec. 2015.

Oyen, M. 2013. Spider silk is a wonder of nature, but it's not stronger than steel. The Conversation, The Conversation US, Inc., 5 June 2013. theconversation.com/spider-silk-is-a-wonder-ofnature-but-its-not-stronger-than-steel-14879. Accessed 29 Nov. 2015.

Palmer, J.M. 1985. The silk and silk production system of the funnel-web mygalomorph spider Euagrus (Araneae, Dipluridae). Journal of Morphology 186.2:195-207.

Palmer, J.M. 1990. Comparative morphology of the external silk production apparatus of "primitive" spiders. Harvard University, Department of Organismic and Evolutionary Biology.

Selden, P.A., and D. Penney. 2010. Fossil spiders. Biological Reviews 85.1:171-206.

Senff-Ribeiro, A., et al. 2008. Biotechnological applications of brown spider (Loxosceles genus) venom toxins. Biotechnology Advances 26.3: 210-218.

Servheen, C., H. Stephen, and B. Peyton. 2009. Bears: Status Survey and Conservation Action Plan. IUCN. International Union for Conservation of Nature, $\quad$ portals.iucn.org/library/node/7503. Accessed 29. Nov. 2015.

Shear, W.A., et al. 1989. A Devonian spinneret: Early evidence of spiders and silk use. Science 246.4929: 479. 
Smithsonian Institution. 2014. Invertebrates ExhibitNational Zoo. Smithsonian National Zoological and Conservation Biology Institute., Washington, DC. nationalzoo.si.edu/news/update-invertebrateexhibit. Accessed 29 Dec. 2015.

University of Wyoming. 2014. Special Saturday University Program pairs UW scientists and artists. University of Wyoming, 11 Jun. 2014, www.uwyo.edu/uw/news/2014/06/specialsaturday-u-program-pairs-uw-scientists-andartists.html. Accessed 6 Dec. 2015.
Utah Statesman. 2011. Spider Man: Spider silk scientist is new USTAR researcher at USU. July 11, 2011 usustatesman.com/spider-man-spider-silkscientist-is-new-ustar-researcher-at-usu/. 31 Dec. 2015

Wilkins T. 1998. Thomas Moran: Artist of the Mountains. University of Oklahoma Press.

Wilson, E.O. 1987. The little things that run the world: The importance and conservation of invertebrates. Conservation Biology 1.4:344-346.

World Spider Catalog. 2015. World Spider Catalog. Natural History Museum Bern. http://www.wsc.nmbe.ch. Accessed 29 Nov. 2015.

Zitkala-Sa. 1985. Iktomi and the Ducks and Other Sioux Stories. University of Nebraska Press. 